\title{
Hydrogeochemistry of sulphur isotopes in the Kalix River catchment, northern Sweden
}

\author{
J. Ingri \\ P. Torssander \\ P.S. Andersson \\ C-M. Mörth
}

\author{
Division of Applied Geology, Lulea University of Technology, \\ S-971 87 Luled, Sweden \\ Department of Geology and Geochemistry, Stockholm \\ University, S-106 91 Stockholm, Sweden \\ Swedish Museum of Natural History, Laboratory for Isotope \\ Geology, Box 50007, S-104 05 Stockholm, Sweden \\ Department of Geology and Geochemistry, Stockholm \\ University, S-106 91 Stockholm, Sweden
}

\section{Introduction}

The $\delta^{34} \mathrm{~S}$ in sulphate in any river represents a mixture of the sulphur derived from the bedrock, soil and the atmosphere. However, the original isotope ratios might be modified by fractionation processes in the river and its watershed. Assimilatory reduction in soils fractionate sulphur only to a small extent but the amount of sulphur cycled can be substantial (Fuller $e t$ al., 1986). Adsorption-desorption processes in soils fractionate very little or not at all (van Stempvoort et al., 1990). Studies in peatland have shown that dissimilatory reduction can be an important net sink for sulphur (Urban et al., 1989). Spratt et al. (1987) measured microbial sulphate reduction rates in acidic peat which were similar to rates determined in freshwater lake sediments. This indicate that discharge of mire water into streams and rivers should result in an increase in the $\delta^{34} \mathrm{~S}$ value in the receiving water. Andersson et al. (1992) demonstrated a continuous increase of $\delta^{34} \mathrm{~S}$ in bottom water and at well oxidised intermediate depths during winter in an ice covered lake. Hence, it is plausible that overturn in lakes can be detected as increased $\delta^{34} \mathrm{~S}$ values in receiving streams and rivers.

In this study, frequent sampling (once a week) of sulphur isotopes in the dissolved $(<0.45 \mu \mathrm{m})$ sulphate have been undertaken during one and a half year in the Kalix River, northern Sweden. One objective with this investigation was to study the impact of sulphate reduction, within the catchment, on $\delta^{34} \mathrm{~S}$ values in the river. Another objective was to explore the possibility to use the $\delta^{34} \mathrm{~S}$ value as a tracer for different water masses in the river, especially to trace mire water and bottom water from lakes.

\section{Results}

The dissolved $\mathbf{S}$ concentration in the river varied from $0.6 \mathrm{mgl}^{-1}$, during maximum melt water discharge in May, up to $2.4 \mathrm{mgl}^{-1}$ during low discharge in winter. The $\delta^{34} \mathrm{~S}$ values varied between $+5.63 \%$ and $+7.36 \%$. The $\delta^{34} \mathrm{~S}$ values in the tributaries ranged from $+4.98 \%$ to $+8.46 \%$ during high discharge in May and from $+5.21 \%$ to $+12.07 \%$ in August. The $\delta^{34} \mathrm{~S}$ of sulphate in snow varied between $+5.44 \%$ and $+6.15 \%$. Rain samples ranged from $+3.80 \%$ to $+6.29 \%$.

\section{Discussion}

The average $\delta^{34} \mathrm{~S}$ values in rain and snow were significantly lower than the values measured in the river and most tributaries. We believe that the generally higher $\delta^{34} \mathrm{~S}$ in the catchment and the temporal variations in $\delta^{34} \mathrm{~S}$ observed in the river were caused by sulphate reduction.

In order to locate the major sources for waters with enhanced $34 \mathrm{~S}$ values to the river we have used the dissolved $\mathrm{Mn}$ concentration as a tracer. Dissolved Mn showed peak concentrations shortly before maximum spring discharge in May, in early June and in November. These peaks represents different types of water ( Pontér et al., 1992).

Relatively high $\delta^{34} \mathrm{~S}$ values were measured during snow melt in May in the river. The increase of the $\delta^{34} \mathrm{~S}$ ratio closely followed an increase of dissolved $\mathrm{Mn}$. Both the $\mathrm{Mn}$ concentration and discharge started to increase when the conductivity started to decline. The tributaries which drain peatland showed low conductivity, high $\mathrm{Mn}$ concentrations and relatively high $\delta^{34} \mathrm{~S}$ values during melt water discharge in May. These data indicate that the increase of the $\delta^{34} \mathrm{~S}$ values in 
early May in the river were caused by mire water enriched in ${ }^{34} \mathrm{~S}$. Tributaries which drain peatland showed significantly higher $\delta^{34} \mathrm{~S}$ values during low discharge in August compared with melt water discharge. This was most likely caused by dilution of mire water (high in ${ }^{34} \mathrm{~S}$ ) with melt water (relatively low in ${ }^{34} \mathrm{~S}$ ).

The highest $\delta^{34} \mathrm{~S}$ values coincided with a peak of dissolved $\mathrm{Mn}$ in November. Dissolved $\mathrm{Mn}$ and temperature data indicate that the peak of $\delta^{34} \mathrm{~S}$ was correlated in time with enhanced amount of bottom water from lakes in the catchment. It is likely that the enhanced $\delta^{34} \mathrm{~S}$ values were partly caused by sulphate reduction in bottom water and sediment in lakes in the catchment and a subsequent transport to the river during overturn. Evidence for sulphate reduction has been detected both in bottom water in lakes within the
Kalix River catchment and in pore water in the river sediment.

\section{References}

Andersson P., Torssander P. and Ingri J. (1992) Hydrobiologia, 235/236, 205-17.

Fuller R.D., Driscoll R.T., Schindler S.C. and Mitchell M.J. (1986) Biogeochemistry, 2, 313-28. Pontér, C., Ingri, J. and Boström, K. (1992) Geochim. Cosmochim. Acta, 56, 1485-94.

Spratt H.G., Morgan M.D. and Good R.E. (1987) Appl. Environ. Microbiol., 53, 1406-11.

Urban N.R., Eisenreich S.J. and Grigal D.F. (1989) Biogeochemistry, 7, 81-109.

van Stempvoort D.R., Rerdon E.J., Fritz,P. (1990) Geochim. Cosmochim. Acta, 54, 2817-26. 